\begin{abstract}
Background: Acute renal failure is a dose-limiting factor of cisplatin chemotherapy. Here, we show the protective effect of ozone oxidative preconditioning against cisplatin-induced renal dysfunction in rats. Ozone oxidative preconditioning is a prophylactic approach, which favors the antioxidant-pro-oxidant balance for preservation of the cell redox state by increasing antioxidant endogenous systems in various in vivo and in vitro experimental models.

Aims: To analyze the protective role of ozone oxidative preconditioning against cisplatin-induced nephrotoxicity.

Methods: Male Sprague-Dawley rats were pretreated with 15 intrarectal applications of ozone/oxygen mixture at $0.36,0.72,1.1,1.8$ and $2.5 \mathrm{mg} / \mathrm{kg}$ before cisplatin intraperitoneal injection $(6 \mathrm{mg} / \mathrm{kg})$. Serum and kidneys were extracted and analyzed 5 days after cisplatin treatment for determinations of the renal content of glutathione, thiobarbituric acid-reactive substances, renal concentration and enzymatic activities of catalase, superoxide dismutase and glutathione peroxidase.

Results: Ozone pretreatment prevented the increase in serum creatinine levels, the glutathione depletion and the inhibition of superoxide dismutase, catalase and glutathione peroxidase activities induced by cisplatin in the rat kidney. Also, the renal content of thiobarbituric acid-reactive substances was decreased by ozone therapy. These protective effects of ozone were dose dependent.

Conclusions: Intrarectal ozone therapy prevented effectively the renal antioxidant unbalance induced by cisplatin treatment.
\end{abstract}

Key words: Ozone oxidative preconditioning, Cisplatininduced nephrotoxicity, Antioxidant defenses, Lipid peroxidation

\section{Protection by ozone preconditioning is mediated by the antioxidant system in cisplatin-induced nephrotoxicity in rats}

\author{
Aluet Borrego ${ }^{1, C A}$, Zullyt B. Zamora ${ }^{1}$, \\ Ricardo González ${ }^{1}$, Cheyla Romay ${ }^{1}$, \\ Silvia Menéndez ${ }^{1}$, Frank Hernández ${ }^{1}$, \\ Teresita Montero ${ }^{2}$ and Enys Rojas ${ }^{1}$
}

${ }^{1}$ Department of Biomedicine, Ozone Research Center National Center for Scientific Research, Biomedicine Department, P.O. Box 6414, Havana City, Cuba; ${ }^{2 ` D r}$. Luis Díaz Soto' Surgical and Clinical Hospital, Havana City, Cuba

\author{
${ }^{\mathrm{CA}}$ Corresponding author \\ Tel: + 5372712324 \\ E-mail: ozono@infomed.sld.cu
}

\section{Introduction}

Cisplatin (CDDP) is an effective chemotherapeutic agent commonly used in the treatment of a variety of solid-organs cancers, including those of the head, neck, testis, ovary and breast. ${ }^{1}$ Unfortunately, $28-36 \%$ of patients receiving a dose of CDDP develop acute renal failure. ${ }^{1}$ Therefore, its pathogenesis has been the focus of many investigations, which have shown that acute renal failure induced by CDDP is accompanied by the reduced renal blood flow associated with increased renal vascular resistance and histological damage to the proximal tubular cells. $^{2,3}$

Additionally, evidence is available that the cellular events in CDDP-mediated nephrotoxicity, including apoptosis induction, decreased protein synthesis, membrane peroxidation, mitochondrial dysfunction and DNA injury, are a consequence of reactive oxygen species (ROS) generation, which produces oxidative renal damage. ${ }^{4-9}$ Thus, administration of CDDP causes depletion of renal reduced glutathione (GSH) and an increase of lipid peroxidation accompanied with a decrease in the activity of enzymes that protect against lipid peroxidation in the kidney, such as superoxide dismutase (SOD), catalase (CAT) and glutathione peroxidase (GSH-Px). ${ }^{4-9}$

In agreement with this, administration of known antioxidant molecules like vitamin E, ascorbic acid, ebselen, lipoic acid, GSH and its esters, CAT and the SOD mimetic orgotein, among others, have shown nephroprotective effects in CDDP-treated rats. ${ }^{10-16}$

Recently it was reported that oxidative preconditioning with ozone prevents renal damage in rats submitted to warm ischemia, ${ }^{17}$ suggesting that oxidative preconditioning with ozone may provide a prophylactic approach for minimizing renal damage before transplantation, which is also mediated by ROS production. Taking into account these findings, we decided to evaluate the role of ozone oxidative 
preconditioning in CDDP-induced acute renal damage in rats and to determine its potential protective effects on some important constituents of the antioxidant system in the kidney.

\section{Materials and methods}

\section{Chemicals}

Serum creatinine (Cr) was measured spectrophotometrically with the $\mathrm{Cr}$ assay kits purchased from Biological Products Enterprise 'Carlos J Finlay' (Havana, Cuba). All reagents used in determinations of GSH, SOD, CAT, GSH-Px, thiobarbituric acidreactive substances (TBARS) and cisplatin were purchased from Sigma Chemicals (St Louis, MO, USA). Other reagents of analytical grade were obtained from normal commercial sources.

\section{Animals}

Male Sprague-Dawley rats (200-250 g) were obtained from the National Center for Laboratory Animal Production (CENPALAB, Havana Cuba). The animals were housed under a $12 \mathrm{~h}$ light-dark cycle with room temperature maintained at $25^{\circ} \mathrm{C}$, humidity at $60 \%$ and food and water available ad libitum. The experiments were conducted in accordance with the ethical guidelines for investigations in laboratory animals and were approved by the Ethical Committee for Animal Experimentation of the National Center for Scientific Research, Havana, Cuba.

\section{Experimental design}

Ozone $\left(\mathrm{O}_{3}\right)$ was generated by an OZOMED 01 equipment manufactured by the Ozone Research Center (Cuba). $\mathrm{O}_{3}$ obtained from medical-grade oxygen $\left(\mathrm{O}_{2}\right)$ was used immediately. The $\mathrm{O}_{3}$ concentration was measured using an ultraviolet spectrophotometer at $254 \mathrm{~nm}$. An $\mathrm{O}_{3} / \mathrm{O}_{2}$ mixture was administered by rectal insufflations (i.r.) at doses of $0.36,0.72,1.1,1.8$ and $2.5 \mathrm{mg} / \mathrm{kg}$. The volume of insufflated mixture was approximately $9 \mathrm{ml}$. Oxidative preconditioning was performed with 15 applications (one daily) of the $\mathrm{O}_{3} / \mathrm{O}_{2}$ mixture. CDDP was applied 1 day after the 15 applications of the $\mathrm{O}_{3} / \mathrm{O}_{2}$ mixture by an intraperitoneal injection $(6 \mathrm{mg} /$ $\mathrm{kg}$ ). Five days after CDDP injection, animals were sacrificed by asphyxia in ether.

The animals were divided into 10 groups of seven rats each: (1) non-treated control rats, (2) rats treated with $\mathrm{O}_{2}$, (3) rats treated with $\mathrm{O}_{3} / \mathrm{O}_{2}$ mixture $(1.1 \mathrm{mg}$ / $\mathrm{kg}$ ), (4) rats treated with $\mathrm{O}_{2}+\mathrm{CDDP},(5)$ rats treated only with CDDP, (6) rats treated with $\mathrm{O}_{3} / \mathrm{O}_{2}$ mixture (10 $\mu \mathrm{g}$ of ozone $/ \mathrm{ml}$ of mixture at a dose of $0.36 \mathrm{mg} /$ $\mathrm{kg})+\mathrm{CDDP}$, (7) rats treated with $\mathrm{O}_{3} / \mathrm{O}_{2}$ mixture
(20 $\mu \mathrm{g}$ of ozone $/ \mathrm{ml}$ of mixture at a dose of 0.72 $\mathrm{mg} / \mathrm{kg})+\mathrm{CDDP}$, (8) rats treated with $\mathrm{O}_{3} / \mathrm{O}_{2}$ mixture (30 $\mu \mathrm{g}$ of ozone $/ \mathrm{ml}$ of mixture at a dose of $1.1 \mathrm{mg} /$ $\mathrm{kg})+\mathrm{CDDP}$, (9) rats treated with $\mathrm{O}_{3} / \mathrm{O}_{2}$ mixture (50 $\mu \mathrm{g}$ of ozone $/ \mathrm{ml}$ of mixture at a dose of $1.8 \mathrm{mg} /$ $\mathrm{kg})+\mathrm{CDDP}$, and (10) rats treated with $\mathrm{O}_{3} \mathrm{O}_{2}$ mixture (70 $\mu \mathrm{g}$ of ozone $/ \mathrm{ml}$ of mixture at a dose of $2.5 \mathrm{mg} /$ $\mathrm{kg})+$ CDDP. Rats were killed 5 days after CDDP injection by an overdose of ether. The blood was collected and serum was separated by centrifugation for $\mathrm{Cr}$ analysis. The kidneys were dissected and immediately frozen at $-20^{\circ} \mathrm{C}$ until analysis could be completed.

Kidney homogenates were obtained using a tissue homogenator (Ultraturrax T-25 Polytron) at $4{ }^{\circ} \mathrm{C}$. The homogenates were prepared by using a $100 \mathrm{mM} \mathrm{KCl}$ buffer ( $\mathrm{pH}$ 7) containing $0.3 \mathrm{mM}$ ethylenediamine tetraacetic acid (1:10 w/v) for GSH, TBARS, GSH-Px and SOD determinations (Buffer 1). The homogenates were spun down with a centrifuge at $600 \times g$ for $60 \mathrm{~min}$ at $4^{\circ} \mathrm{C}$. The supernatants were taken for biochemical determinations.

Kidney homogenates for CAT enzymatic assay were carried out using $50 \mathrm{mM}$ phosphate buffer $(\mathrm{pH} 7)$ containing $1 \%$ Triton X-100 (1:9 w/v) (Buffer $2)$. The homogenates were centrifuged at $600 \times g$ for $60 \mathrm{~min}$ at $4^{\circ} \mathrm{C}$ and the supernatants were used for the CAT assay.

\section{Determination of GSH}

GSH was determined by a slightly modified version of the method of Beutler et al., ${ }^{18}$ using a spectrophotometer. One milliliter of the kidney homogenate, as described earlier, was mixed with $1.5 \mathrm{ml}$ of $5 \%$ metaphosphoric acid and centrifuged at $3000 \times g$ for $10 \mathrm{~min}$ at room temperature. Fifty hundred microliters of this acidic supernatant was mixed with $2 \mathrm{ml}$ of $0.2 \mathrm{M}$ phosphate buffer and $0.25 \mathrm{ml}$ of $0.04 \% 5$, 5'-dithio-bis(-2-nitrobenzoic acid). Absorbance of the yellow solution was measured at $412 \mathrm{~nm}$ within 10 min. A molar extinction coefficient of $13.6 \mathrm{M} / \mathrm{cm}$ that describes the formation of the thiolate anion by the reaction of sulfhydryl groups with 5,5'-dithio-bis-2nitrobenzoic acid at $412 \mathrm{~nm}$ was used to quantify GSH.

\section{Determination of SOD activity}

Enzymatic activity of SOD was determined by a modified version of the method of Minami and Yoshikawa. ${ }^{19}$ Fifty microliters of the kidney homogenate was mixed with $450 \mu$ l of cold deionized water, $125 \mu \mathrm{l}$ of chloroform and $250 \mu \mathrm{l}$ of ethanol. The mixture was centrifuged at $8000 \times g$ for $2 \mathrm{~min}$ at $4^{\circ} \mathrm{C}$. Fifty hundred microliters of the extract was added to the reaction mixture containing $500 \mu \mathrm{l}$ of $72.4 \mathrm{mM}$ Tris cacodylate buffer with $3.5 \mathrm{mM}$ diethy- 
lene pentaacetic acid ( $\mathrm{pH} 8.2$ ), $100 \mu \mathrm{l}$ of $16 \%$ Triton-X 100 and $250 \mu \mathrm{l}$ of $0.9 \mathrm{mM}$ nitro blue tetrazolium. The reaction mixture was incubated for $5 \mathrm{~min}$ at $37^{\circ} \mathrm{C}$ before adding $10 \mu \mathrm{l}$ of $9 \mathrm{mM}$ pyrogallol (dissolved in $10 \mathrm{mM}$ hydrochloric acid), and then it was incubated for exactly $5 \mathrm{~min}$ at $37^{\circ} \mathrm{C}$. The reaction was stopped with the addition of $300 \mu \mathrm{l}$ of $2 \mathrm{M}$ formic buffer (pH 3.5) containing 16\% Triton-X 100. The absorbance was measured at $540 \mathrm{~nm}$ in the spectrophotometer. One unit of SOD enzymatic activity is equal to the amount of enzyme that diminishes the initial absorbance of nitro blue tetrazolium by $50 \%$.

\section{Determination of CAT activity}

CAT was determined according to the method of Evans and Diplock. ${ }^{20}$ Kidney homogenate was diluted with Buffer 2, as already described, to obtain an adequate dilution of the enzyme. Then, $2 \mathrm{ml}$ of the enzyme dilution were added to the cuvette and mixed with $1 \mathrm{ml}$ of $30 \mathrm{mM} \mathrm{H}_{2} \mathrm{O}_{2}$, and then the absorbance was measured at $240 \mathrm{~nm}$, for $30 \mathrm{sec}$, in the spectrophotometer. Initial absorbance of the reaction mixture must be around 0.5 . The enzyme activity is expressed as the first-order constant that describes the decomposition of $\mathrm{H}_{2} \mathrm{O}_{2}$ at room temperature.

\section{Determination of GSH-Px activity}

Enzymatic activity of GSH-Px was measured using a modified version of the method of Thonson et al. ${ }^{21}$ All reaction mixtures were dissolved in $20 \mathrm{mM}$ sodium phosphate buffer containing $6 \mathrm{mM}$ ethylenediamine tetraacetic acid $(\mathrm{pH} 7.0)$. The reaction mixture consisted of $98.8 \mu \mathrm{l}$ of phosphate buffer, $700 \mu \mathrm{l}$ of $2.86 \mathrm{mM} \mathrm{GSH}, 100 \mu \mathrm{l}$ of $1 \mathrm{mM}$ sodium azide, $100 \mu \mathrm{l}$ of $1 \mathrm{mM}$ NADPH and $4.2 \mu \mathrm{l}$ of GSH reductase $(0.5 \mathrm{u})$. Then, $10 \mu \mathrm{l}$ of the tissue homogenate supernatant were added to the reaction mixture and incubated at room temperature for 10-15 $\mathrm{min}$. Afterward, $10 \mu \mathrm{l}$ of $30 \mathrm{mM} t$-butyl hydroperoxide (dissolved in bidistilled water) was added to the reaction mixture and measured at $340 \mathrm{~nm}$ for $7 \mathrm{~min}$ in the spectrophotometer. A molar extinction coefficient of $6.22 \times 10^{3} \mathrm{M} / \mathrm{cm}$ was used to determine the activity of GSH-Px. The enzyme activity is expressed as international units of enzymatic activity per milligram of protein. International units are expressed as micromoles of hydroperoxides transformed per minute per milliliter of enzyme.

\section{Lipid peroxidation assay}

This assay was used to estimate TBARS levels as described by Ohkawa et al. ${ }^{22}$ Two hundred milliliters of tissue homogenate supernatant were added to 100 $\mu \mathrm{l}$ of sodium dodecyl sulfate, $750 \mu \mathrm{l}$ of $20 \%$ acetic acid
(pH 3.5), $750 \mu \mathrm{l}$ of $0.6 \%$ thiobarbituric acid and $300 \mu \mathrm{l}$ of distilled water, and were incubated at $95^{\circ} \mathrm{C}$ for 60 min. The samples were allowed to cool at room temperature. Then $2.5 \mathrm{ml}$ of butanol:pyridine (15:1) and $500 \mu \mathrm{l}$ of distilled water were added, vortexed, and centrifuged at $2000 \times g$ for $15 \mathrm{~min}$. The absorbance of three $\mathrm{ml}$ of the colored layer was measured at $532 \mathrm{~nm}$ spectrophotometrically using 1,1,3,3tetraethoxypropane as standard.

\section{Protein assay}

Protein concentrations were determined by the method of Lowry ${ }^{23}$ using bovine serum albumin as standard.

\section{Histopathological assessment of renal damage}

The left kidneys were quickly removed and fixed in $10 \%$ formaldehyde. Tissues were embedded in paraffin, sectioned at $3 \mu \mathrm{m}$, stained with hematoxylin and eosin $(\mathrm{H} / \mathrm{E})$ and evaluated by light microscopy.

\section{Statistical analysis}

Data are expressed as means \pm standard error of the mean and analyzed statistically using one-way analysis of variance followed by the Duncan multiple range test for serum $\mathrm{Cr}$ determinations, whereas the Kruskall-Wallis test followed by the Mann-Whitney test was applied for the rest of the markers. The 0.05 level of probability was used as statistical significance.

\section{Results}

Loss of body weight in all animals was observed 5 days after CDDP injection. The mean reduction in body weight was approximately $16 \mathrm{~g}$, which represents $8 \%$ of the initial body weight. This effect on body weight was not reversed in animal groups under $\mathrm{O}_{3}$ therapy with mixtures of $\mathrm{O}_{3} / \mathrm{O}_{2}$ administered by rectal insufflation.

The levels of $\mathrm{Cr}$ in the blood serum of control and experimental rats are presented in Table 1. After CDDP injection, Cr levels increased about four-fold at day 5 with respect to non-treated controls. However, there were no significant differences in the concentrations of $\mathrm{Cr}$ in rat serum between the non-treated controls and those only treated with $\mathrm{O}_{2}$. No significant differences in Cr levels were found between the group treated with CDDP alone and the other one with $\mathrm{CDDP}+\mathrm{O}_{2}$. In contrast, oxidative preconditioning with $\mathrm{O}_{3} / \mathrm{O}_{2}$ mixture during 15 days at doses of 0.72 and $1.1 \mathrm{mg} / \mathrm{kg}$ but not $0.36 \mathrm{mg} / \mathrm{kg}$ induced a remarkable decrease in $\mathrm{Cr}$ levels in serum with 
respect to the higher values in CDDP group. Greater doses of 1.8 and $2.5 \mathrm{mg} / \mathrm{kg}$ did not significantly decrease Cr (Table 1).

The concentration of renal reduced GSH was significantly decreased ( $58 \%$ of non-treated control) in CDDP-treated rats. Ozone therapy $(0.72,1.1,1.8$ and $2.5 \mathrm{mg} / \mathrm{kg}$ i.r.) prevented renal GSH depletion induced by CDDP. This effect was greater at doses of 0.72 and $1.1 \mathrm{mg} / \mathrm{kg}(p<0.01)$. The lowest dose of $\mathrm{O}_{3}$ $(0.36 \mathrm{mg} / \mathrm{kg})$ was not effective in the prevention of GSH depletion.(Table 1).

The kidney TBARS content used as a measure of lipid peroxidation was significantly increased in rats treated with CDDP alone, as compared with nontreated controls. Oxidative preconditioning with $\mathrm{O}_{3} / \mathrm{O}_{2}$ mixture during 15 days induced significant decrease in TBARS content at $\mathrm{O}_{3}$ doses of $0.72 \mathrm{mg} / \mathrm{kg}$ $(p<0.05), \quad 1.1 \mathrm{mg} / \mathrm{kg} \quad(p<0.001), \quad 1.8 \mathrm{mg} / \mathrm{kg}$ $(p<0.001)$ and $2.5 \mathrm{mg} / \mathrm{kg}(p<0.01)$ as compared with CDDP alone. The lower $\mathrm{O}_{3}$ dose $(0.36 \mathrm{mg} / \mathrm{kg})$ did not induce any significant change on renal TBARS content. The data indicate that the induction of lipid peroxidation made by CDDP in the kidney is attenuated by $\mathrm{O}_{3}$ therapy in a dose-dependent manner (Table 1).

SOD activity in the kidney was significantly decreased ( $71 \%$ of non-treated control) in CDDP-treated rats (Table 1). Pretreatment with $\mathrm{O}_{3} / \mathrm{O}_{2}$ mixtures $(0.72$ and $1.1 \mathrm{mg} / \mathrm{kg})$ significantly increased $(p<0.01)$ SOD activity in CDDP-treated animals, which was close to values of non-treated control. However, the lower $\mathrm{O}_{3}$ dose $(0.36 \mathrm{mg} / \mathrm{kg})$ and the greater ones $(1.8$ and $2.5 \mathrm{mg} / \mathrm{kg})$ did not avoid the decreasing in SOD activity. On the contrary, the greatest $\mathrm{O}_{3}$ tested dose $(2.5 \mathrm{mg} / \mathrm{kg})$ induced a remarkable and significant decrease $(p<0.01)$ of SOD activity $(3.05 \pm 0.48)$ versus $(6.2 \pm 0.9)$ in the CDDP-treated control, which provides evidence of its deleterious effect on this antioxidant enzyme.
CAT activity in the rat kidney was significantly decreased (63\% of non-treated control) in CDDPtreated rats. Pretreatment with $\mathrm{O}_{3}(0.72,1.1,1.8$ and $2.5 \mathrm{mg} / \mathrm{kg}$, but not $0.36 \mathrm{mg} / \mathrm{kg}$ ) significantly prevented $(p<0.05)$ the inhibitory effect of CDDP on CAT activity (Table 1).

GSH-Px activity in the kidney was significantly decreased ( $82 \%$ of non-treated control) in CDDPtreated rats. $\mathrm{O}_{3}$ pretreatment $(0.72$ and $1.1 \mathrm{mg} / \mathrm{kg})$ significantly increased, almost twice $(p<0.01)$, the GSH-Px activity with respect to both CDDP-treated control rats and non-treated rats. The greater $\mathrm{O}_{3}$ doses $(1.8$ and $2.5 \mathrm{mg} / \mathrm{kg})$ induced a minor increase on the enzyme activity (Table 1 ).

The histopathological changes in the kidney tissue are reported in Fig. 1. Non-treated rats exhibited cellular tumefaction, probably due to the type of euthanasia (asphyxia by ether) (Fig. 1A). Rats treated with CDDP alone revealed intense tubular necrosis, desquamation of renal tubular cells, and cast formation in the lumen, as reported in previous works (Fig. 1B). O $\mathrm{O}_{3}$-treated rats with $1.1 \mathrm{mg} / \mathrm{kg}$ showed a moderate cellular tumefaction, revealing no significant differences between them and nontreated rats. At greater doses of 1.8 and $2.5 \mathrm{mg} / \mathrm{kg}$ doses, histopathological changes in renal tissue were quite similar to those present in CDDP-treated rats. $\mathrm{O}_{3}$ oxidative preconditioning provided significant protection against CDDP-induced nephrotoxicity, and the majority of the treated animals showed no significant histopathological alterations (Fig. 1C).

\section{Discussion}

The aim of this work was to determine the effect of $\mathrm{O}_{3}$ oxidative preconditioning on the severity of CDDP-induced nephrotoxicity. In the present study, CDDP-induced acute kidney damage was character-

Table 1. Biochemical determinations in experimental groups

\begin{tabular}{|c|c|c|c|c|c|c|}
\hline Experimental groups & $\begin{array}{l}\text { Serum Cr } \\
\text { levels }(\mu \mathrm{M})\end{array}$ & $\begin{array}{l}\mathrm{GSH}(\mathrm{nmol} / \mathrm{mg} \\
\text { of protein) }\end{array}$ & $\begin{array}{l}\text { TBARS (nmol/ } \\
\text { mg of protein) }\end{array}$ & $\begin{array}{l}\text { SOD (SOD units/ } \\
\text { mg of protein) }\end{array}$ & $\begin{array}{l}\text { CAT }\left(k_{15} / g \text { of }\right. \\
\text { wet tissue })\end{array}$ & $\begin{array}{c}\text { GSH-Px (IU/mg } \\
\text { of protein) }\end{array}$ \\
\hline Non & $1.73^{*}$ & $9.3 \pm$ & 0.25 & 8.7 & 6.8 & $6.0=$ \\
\hline Oxygen-treated control & 70 & $8.9 \pm 0.96$ * & $0.26 \pm 0.012^{*}$ & $8.8 \pm 1.26^{*}$ & $6.7 \pm 0.63^{*}$ & $6.1 \pm 0.14^{*}$ \\
\hline Ozone-treated control & $69.2 \pm 7.61^{*}$ & $8.5 \pm 0.47^{*}$ & $0.31 \pm 0.034^{*}$ & $8.6 \pm 1.72^{*}$ & $6.7 \pm 1.56^{*}$ & $6.1 \pm 0.14^{*}$ \\
\hline CDDP control & $280.6 \pm 45.05$ & $5.4 \pm 0.76$ & $0.63 \pm 0.12$ & $6.2 \pm 0.9$ & $4.3 \pm 0.74$ & $5.3 \pm 0.69$ \\
\hline $\mathrm{O}_{2}-\mathrm{CDDP}$ control & & & 0.029 & & 4.3 & $5.5 \pm$ \\
\hline $\mathrm{O}_{3}(0.36 \mathrm{mg} / \mathrm{kg})+\mathrm{CDDP}$ & $294.9 \pm 47.70$ & $6.6 \pm 1.34$ & $0.54 \pm 0.077$ & $6.8 \pm 1.23$ & $5.2 \pm 0.79$ & $5.9 \pm 0.98$ \\
\hline $\mathrm{O}_{3}(0.72 \mathrm{mg} / \mathrm{kg})+\mathrm{CDDP}$ & $106.0 \pm 29.78^{*}$ & $12.3 \pm 1.17^{*}$ & $0.48 \pm 0.049$ & $9.1 \pm 0.81 *$ & $5.5 \pm 0.67^{*}$ & $10.5 \pm 1.03^{*}$ \\
\hline $\mathrm{O}_{3}(1.1 \mathrm{mg} / \mathrm{kg})+\mathrm{CDDP}$ & $130.4 \pm 30.41^{*}$ & $13.4 \pm 2.7^{*}$ & $0.29 \pm 0.062^{*}$ & $9.1 \pm 1.01^{*}$ & $6.0 \pm 0.54 *$ & $7.9 \pm 1.32^{*}$ \\
\hline $\mathrm{O}_{3}(1.8 \mathrm{mg} / \mathrm{kg})+\mathrm{CDDP}$ & $288.4 \pm 47.81$ & $10.9 \pm 1.57 *$ & $0.22 \pm 0.03^{*}$ & $6.1 \pm 0.9$ & $5.9 \pm 0.57 *$ & $5.8 \pm 0.89 *$ \\
\hline $\mathrm{O}_{3}(2.5 \mathrm{mg} / \mathrm{kg})+\mathrm{CDDP}$ & $392.9 \pm 47.56$ & $10.6 \pm 1.76 *$ & $0.28 \pm 0.033^{*}$ & $3.0 \pm 0.48^{*}$ & $6.1 \pm 64^{*}$ & $5.7 \pm 0.62 *$ \\
\hline
\end{tabular}

Data presented as (mean \pm standard error of the mean. Serum $\mathrm{Cr}$ was measured with the Cr assay kits (Biological Products Enterprise 'Carlos $\mathrm{J}$ Finlay', Havana, Cuba). GSH was determined by the method of Beutler et al. ${ }^{18}$ Enzymatic activity of SOD was determined by a version of the method of Minami and Yoshikawa ${ }^{19}$ (one unit of SOD enzymatic activity is equal to the amount of enzyme that diminishes the initial absorbance of nitro blue tetrazolium by $50 \%$ ). CAT was determined according to the method of Evans and Diplock ${ }^{20}$ (the enzyme activity is expressed as the first-order constant that describes the decomposition of hydrogen peroxide at room temperature). Enzymatic activity of GSH-Px was measured using a modified version of the method of Thonson et al. ${ }^{21}$ (the enzyme activity is expressed as international units of enzymatic activity per milligram of protein). TBARS levels were estimated by Ohkawa et al. ${ }^{22}$ Protein concentrations were determined by the method of Lowry. ${ }^{23} *$ Significant differences with CDDP-treated control groups $(p<0.05)$. 

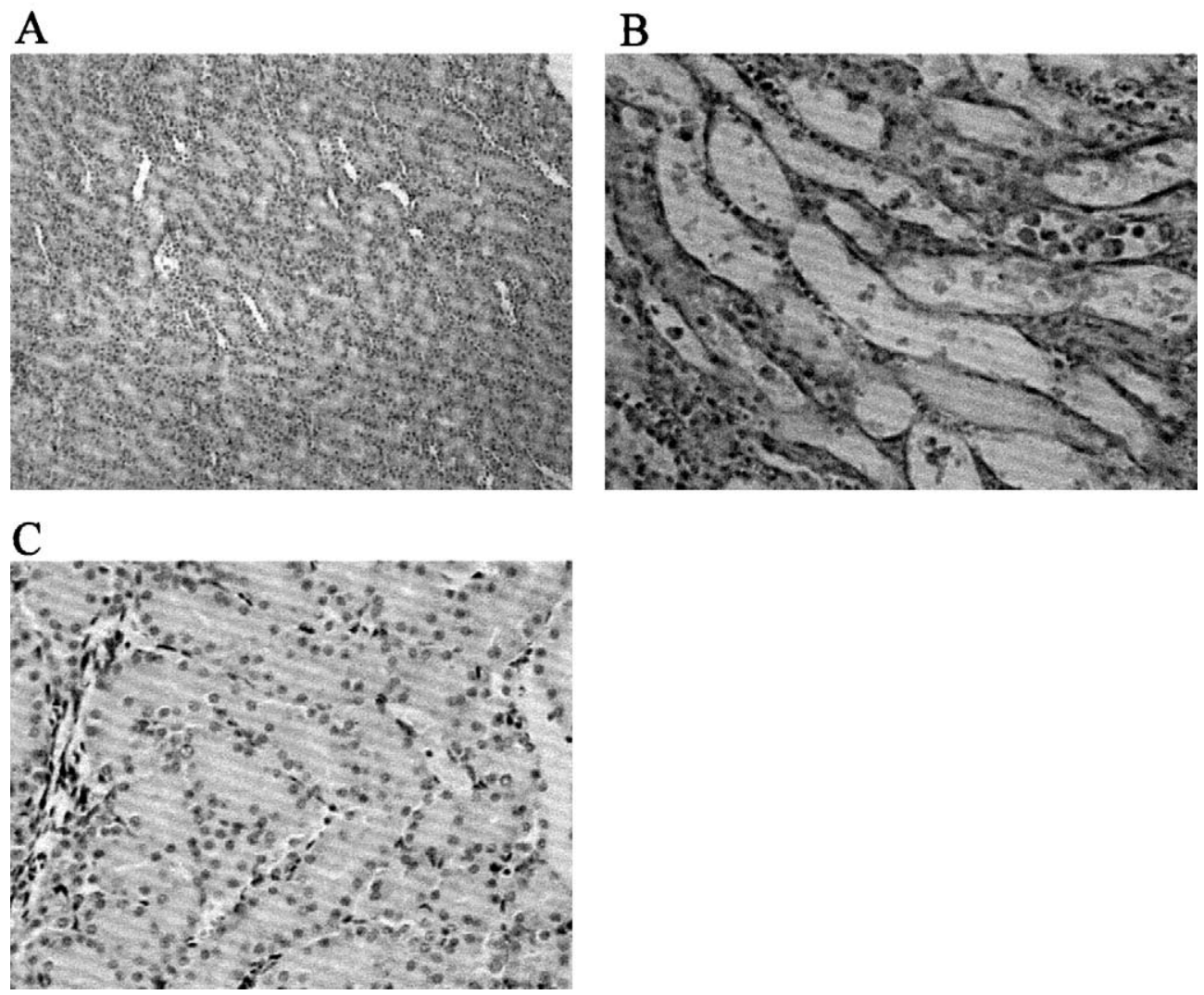

FIG. 1. Histopathological changes in rat kidneys after CDDP administration $(6 \mathrm{mg} / \mathrm{kg})$ and under i.r. $\mathrm{O}_{3}$ therapy. (A) Light micrograph of rat kidneys from the control group. Slight cellular tumefaction ascribed to the type of euthanasia (asphyxia by ether). $H / E$ stain, $\times 100$. (B) Light micrograph from a CDDP-treated rat. Note the widespread tubular necrosis and cast formation in the tubular lumen. $\mathrm{H} / \mathrm{E}$ stain, $\times 100$. (C) Light micrograph of a rat kidney, which received 15 applications of $\mathrm{O}_{3}(1.1$ $\mathrm{mg} / \mathrm{kg}$ ) by rectal insufflation before CDDP injection. Moderate cellular tumefaction was observed. H/E stain, $\times 100$.

ized by a significant increase in serum $\mathrm{Cr}$, decreases in the kidney GSH content and GSH-Px, SOD and CAT activities, and an increase in TBARS production in comparison with the non-treated controls. Histopathological examination of the kidneys of CDDPtreated rats revealed marked tubular necrosis and desquamation of renal tubular cells. These results are in accordance with previous reports. ${ }^{4-16}$

The mechanisms underlying CDDP-induced nephrotoxicity have not been fully elucidated. Several investigators have shown that ROS are closely related to the nephrotoxicity induced by CDDP. ${ }^{5-7,14}$ It has also been reported that the inordinate generation of ROS contributes to the initiation and/or maintenance of acute tubular necrosis. ${ }^{5-7,14}$ Indeed, several antioxidants such as SOD, ebselen, vitamin E and vitamin $\mathrm{C}$ are reported to attenuate cisplatin-induced renal toxicity. ${ }^{10-16}$ Several reports demonstrate different mechanisms involved in the CDDP-induced nephrotoxicity including protein kinase $\mathrm{C}$ activation, ${ }^{24}$ elevation of caspase-3 activity resulting in renal cell apoptosis, ${ }^{8}$ enhancement of intrarenal synthesis of thromboxane $\mathrm{A}_{2}{ }^{25}$ and dyslipidemia. ${ }^{26}$

Oxidative preconditioning is analogous to other phenomena such as ischemic preconditioning, ${ }^{27}$ thermal preconditioning ${ }^{28}$ and chemical precondi- tioning. ${ }^{29}$ All of these processes have in common that a repeated and controlled stress is able to protect against a prolonged and severe stress.

Intrarectal $\mathrm{O}_{3}$ therapy has conferred protection against hepatic ischemia/reperfusion injury by the adenosine accumulation and by blocking the xanthine/xanthine oxidase pathway, decreasing ROS generation after reperfusion. ${ }^{30-32}$ Recently, it was demonstrated that intrarectal application of an $\mathrm{O}_{3} / \mathrm{O}_{2}$ mixture reduced ROS by stimulation and/or preservation of the endogenous antioxidant systems in experimental models of liver and renal ischemiareperfusion, respectively. ${ }^{30-32}$ Also, there is evidence of an increase in the activity of antioxidant enzymes such as SOD and GSH-Px and a decrease of malondialdehyde after $\mathrm{O}_{3}$ preconditioning in patients with cardiopathy and in rats suffering ischemia/ reperfusion damage. ${ }^{17,33}$

Our experimental results clearly demonstrate that oxidative preconditioning with $\mathrm{O}_{3}$ exerts protective effects in CDDP-induced acute nephrotoxicity in rats. Furthermore, the data provide strong evidence that i.r. $\mathrm{O}_{3}$ therapy effectively prevented a decrease in the renal antioxidant defense system and certainly avoided the deleterious effect of CDDP on it. 
Thus, the pretreatment with $\mathrm{O}_{3} / \mathrm{O}_{2}$ mixture prevented GSH depletion and the decrease of SOD, CAT and GSH-Px activities induced by CDDP in rat kidney. Also, renal TBARS content was diminished by $\mathrm{O}_{3}$ therapy. These protective effects of $\mathrm{O}_{3}$ were dose dependent. The lowest dose of $0.36 \mathrm{mg} / \mathrm{kg}$ did not induce any significant change in the former antioxidant markers. In contrast, the doses of 0.72 and $1.1 \mathrm{mg} / \mathrm{kg}$ significantly reduced serum $\mathrm{Cr}$ and TBARS levels and preserved some constituents of the antioxidant defense, such as GSH content, SOD, CAT and GSH-PX activities, which were levels close to or even greater than those of non treated controls (Table 1).

Furthermore, the preservation of renal SOD, CAT and GSH-PX activities by $\mathrm{O}_{3}$ pretreatment at lower doses $(0.72$ and $1.1 \mathrm{mg} / \mathrm{kg})$ shows that this agent can protect these enzymes even 5 days after CDDP administration. Neither significant change of GSH and TBARS renal content nor statistic differences in CAT activity were found at the greater ozone doses of 1.8 and $2.5 \mathrm{mg} / \mathrm{kg}$ as compared with that of $1.1 \mathrm{mg} /$ $\mathrm{kg}$, which indicates that the 'plateau effect' in the dose-response curves was reached.

Induction of CAT, SOD, and GSH-Px by $\mathrm{O}_{3}$ therapy is probably due to hydrogen peroxide produced as result of $\mathrm{O}_{3}$ decomposition. Hydrogen peroxide has been shown to be one of the major intermediates of $\mathrm{O}_{3}$ decomposition along with oxygen radicals $\left(\mathrm{OH}^{\bullet}\right.$ and $\mathrm{O}_{2}{ }^{\bullet}$ ).

In contrast, the greatest $\mathrm{O}_{3}$ dose $(2.5 \mathrm{mg} / \mathrm{kg})$ induced a marked and significant decrease of SOD activity $(3.05 \pm 0.48 \mathrm{u} / \mathrm{mg}$ of protein) as compared with non-treated controls $(8.72 \pm 1.15 \mathrm{u} / \mathrm{mg}$ of protein), which reveals deleterious effects of ozone treatment on this enzyme, which is probably due to SOD inactivation by $\mathrm{H}_{2} \mathrm{O}_{2}$ at greater concentrations as it has been demonstrated by Marklund. ${ }^{34}$ This author suggested that inactivation of $\mathrm{Cu} \mathrm{Zn}$ SOD by $\mathrm{H}_{2} \mathrm{O}_{2}$ appears to be due to a Fenton-type reaction of $\mathrm{H}_{2} \mathrm{O}_{2}$ with $\mathrm{Cu}$, forming a reactive intermediate that destroys an essential liganding histidine residue of the enzyme. Whiteside and Hassan also demonstrated induction and inactivation of CAT and SOD by ozone in cultures of Escherichia coli. ${ }^{35}$

Furthermore, they showed that an increase in the activities of CAT and SOD by $\mathrm{O}_{3}$ was due to induction of the novo enzyme synthesis rather than activation of pre-existing apoproteins. Thus, the observed induction of SOD, CAT and GSH-Px in response to $\mathrm{O}_{3}$ pretreatment provides further evidence that there is a correlation between antioxidant enzyme biosynthesis and $\mathrm{O}_{3}$ exposure.

Additionally, these authors also showed that the antioxidant enzymes are subjected in vivo to the damaging effects of $\mathrm{O}_{3}$ at relatively high doses. Therefore, in concordance with our results this observation provides evidence that $\mathrm{O}_{3}$, besides inducing the biosynthesis of these enzymes, could also cause inactivation of them by the mechanism previously explained.

In addition, $\mathrm{O}_{3}$ oxidative preconditioning might prevent CDDP-induced acute renal failure through attenuation of renal tubular damage and enhancement of the regenerative response of the damaged tubular cells. As shown in Fig. 1, animals treated with i.r. $\mathrm{O}_{3}$ therapy before CDDP recovered the normal structure of its kidneys 5 days after CDDP administration, showing a moderate cellular tumefaction, in contrast with CDDP-treated rats, which showed severe acute tubular necrosis.

In conclusion, a single dose of CDDP leads to the inhibition of renal antioxidant enzyme activity, depletion of renal GSH levels, increased serum Cr and enhanced renal lipid peroxidation, which cause nephrotoxicity. Our results support the evidence that part of the mechanism of nephrotoxicity in CDDPtreated rats is related to depletion and inhibition of the antioxidant system. Therefore, the prevention of this inhibition in rats protected by i.r. $\mathrm{O}_{3}$ therapy support the potential use of it at low doses to ameliorate CDDP-induced renal injury.

\section{References}

1. Lebwohl D, Canetta R. Clinical development of platinum complexes in cancer therapy: an historical perspective and an update. Eur J Cancer 1998; 34: 1522-1534

2. Winston JA, Safirstein R. Reduced renal blood flow in early cisplatininduced acute renal failure in the rat. Am J Physiol 1985; 249: F490F496.

3. Dobyan DC, Levi J, Jacobs C. Mechanism of cis-platinum nephrotoxicity II. Morphological observations. J Pharmacol Exp Ther 1980; 213: 551 556.

4. Brady HR, Kone BC, Stromski ME. Mitochondrial injury: an early event in cisplatin toxicity to renal proximal tubules. Am J Physiol 1990; 258: F1181-F1187

5. Baliga R, Ueda N, Walker PD. Oxidant mechanisms in toxic acute renal failure. Am J Kidney Dis 1997; 29: 465-477.

6. Matsushima H, Yonemura K, Ohishi K, Hishida A. The role of oxygen free radicals in cisplatin-induced acute renal failure in rats. J Lab Clin Med 1998; 131: 518-526.

7. Nath KA, Norby SM. Reactive oxygen species and acute renal failure. $A m$ J Med 2000; 109: 665-678.

8. Lau AH. Apoptosis induced by cisplatin nephrotoxic injury. Kidney Int 1999; 56: 1295-1298.

9. Zhang JG, Lindup WE. Cisplatin nephrotoxicity: decreases in mitochondrial protein sulphydryl concentration and calcium uptake by mitochondria from rat renal cortical slices. Biochem Pharmacol 1994; 47: 11271135

10. Hussain KC, Morris C, Whitworth GL. Protection by ebselen against cisplatin-induced nephrotoxicity: antioxidant system. Mol Cell Biochem 1998; 178: $127-133$.

11. Appenroth D, Frob S, Kersten L, Splinter FK, Winnefeld K. Protective effect of vitamin $\mathrm{E}$ and $\mathrm{C}$ on cisplatin nephrotoxicity in developing rats. Arch Toxicol 1997; 71: 677-683.

12. Somani SM, Husain K, Whitworth C, Rybak LP. Dose-dependent protection by lipoic acid against cisplatin-induced nephrotoxicity in rats: antioxidant defense system. Pharmacol Toxicol 2000; 86: 234-240.

13. Babu E, Gopal Krishman V, Sriganth IN. Cisplatin induced nephrotoxicity and the modulating effect of glutathione esters. Mol Cell Biochem 1995; 144: 7-11

14. Tsutsumishita $\mathrm{Y}$, Onda T, O Kada K. Involvement of $\mathrm{H}_{2} \mathrm{O}_{2}$ production in cispaltin-induced nephrotoxicity. Biochem Biophys Res Commun 1998; 242: $310-312$.

15. Davis CA, Nick HS, Agarwal A. Manganese superoxide dismutase attenuates cisplatin-induced renal injury: importance of superoxide. J Am Soc Nephrol 2001; 12: 2683-2690. 
16. Sheikh-Hamad D, Timmins K, Jalali Z. Cisplatin-induced renal toxicity: possible reversal by N-acetylcysteine treatment. J Am Soc Nephrol 1997; 8: $1640-1644$

17. Barber E, Menéndez S, León OS, et al. Prevention of renal injury after induction of ozone tolerance in rats submitted to warm ischemia. Mediat Inflamm 1999; 8: 37-41.

18. Beutler F, Duron O, Mikus B. Improved method for the determination of blood glutathione. J Lab Clin Med 1963; 16: 882-889.

19. Minami M, Yoshikawa H. A simplified assay method of superoxide dismutase activity for clinical use. Clin Chim Acta 1979; 92: 337-372.

20. Rice Evans C, Diplock AT. Laboratory techniques in biochemistry and molecular biology. In: Burtin RH, Knippenberg PH, eds. Techniques in Free Radical Research, Amsterdam: Elsevier, 1991: 199-201.

21. Faraji B, Kang HK, Valentine JL. Methods for determining Glutathione peroxidase activity in blood. Clin Chem 1987; 33: 539-543.

22. Ohkawa H, Orishi N, Yagi K. Assay for lipid peroxidation in animals and tissues by thiobarbituric acid reaction. Anal Biochem 1979; 95: $351-$ 358

23. Lowry OH, Rosebrough NJ, Farr AL, Randall RJ. Protein measurement with the Folin phenol reagent. J Biol Chem 1951; 193: 165-175.

24. Ikeda S, Fukuzaki A, Kaneto H, Ishidoya S, Orikasa S. Role of protein kinase C in cisplatin nephrotoxicity. Int J Urol 1999; 6: 245-250.

25. Blochl-Daum B, Pehamberger H, Kurz C, et al. Effects of cisplatin on urinary thromboxane B2 excretion. Clin Pharmacol Ther 1995; 58 $418-424$

26. Abdel-Gayoum AA, El-Jenjan KB, Ghwarsha KA. Hyperlipidemia in cisplatin-induced nephrotoxic rats. Hum Exp Toxicol 1999; 18: $454-$ 459.

27. Murry CE, Richard VJ, Reimer KA, Jennings RB. Ischemic preconditioning slows energy metabolism and delays ultrastructural damage during a sustained ischemic episode. Circ Res 1990; 66: 913-931.
28. Neschis DG, Safford SD, Raghunath PN, et al. Thermal preconditioning before rat arterial balloon injury: limitation of injury and sustained reduction of intimal thickening. Thromb Vasc Biol 1998; 18: 120-126.

29. Riepe MW, Ludolph AC. Chemical preconditioning: a cytoprotective strategy. Mol Cell Biochem 1997; 174: 249-254

30. León OS, Menéndez S, Merino N, et al. Ozone oxidative preconditioning: a protection against cellular damage by free radicals. Mediat Inflamm 1998; 7: 289-294.

31. Peralta C, León OS, Xaus C, et al. Protective effect of ozone treatment on the injury associated with hepatic ischemia-reperfusion: antioxidantprooxidant balance. Free Radic Res 1999; 31: 191-196.

32. Peralta C, Xaus C, Bartrons R, León OS, Gelpí E, Roselló-Catafau J. Effect of ozone treatment on reactive oxygen species and adenosine production during hepatic ischemia-reperfusion. Free Radic Res 2000; 33: 595605 .

33. Hernández F, Menéndez S, Wong R. Decrease of blood cholesterol and stimulation of antioxidative response in cardiopathy patients treated with endovenous ozone therapy. Free Radic Biol Med 1995; 19: 115119

34. Marklund SL. Properties of extracellular superoxide dismutase from human lung. Biochem J 1984; 220: 269-272

35. Whiteside $C$, Hassan $\mathrm{HM}$. Induction and inactivation of catalase and superoxide dismutase of Escherichia coli by ozone. Arch Biochem Biophys 1987; 257: 464-471.

\section{Received 6 October 2003 \\ Accepted 30 October 2003}




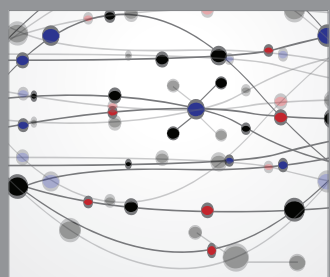

The Scientific World Journal
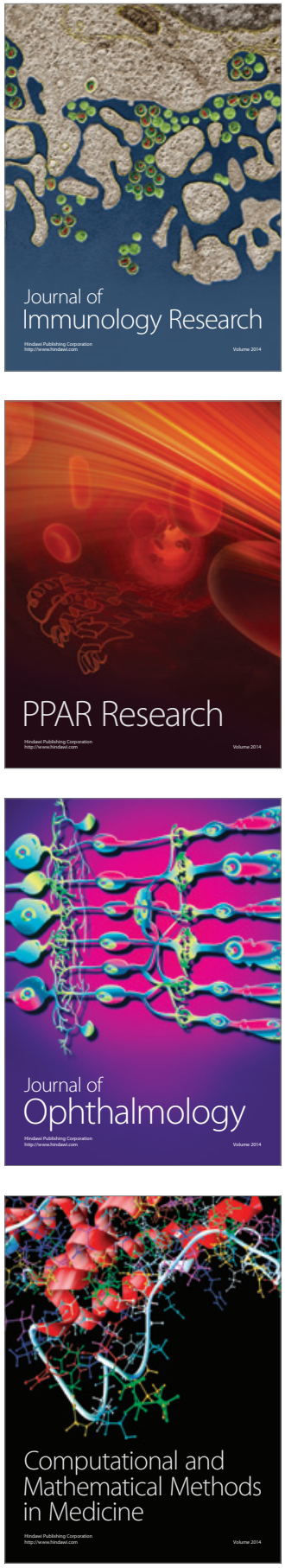

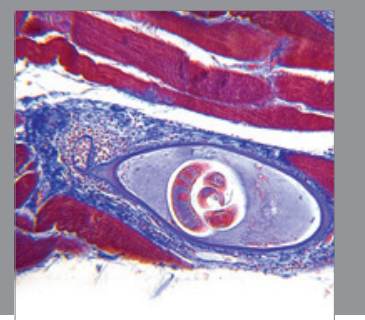

Gastroenterology

Research and Practice
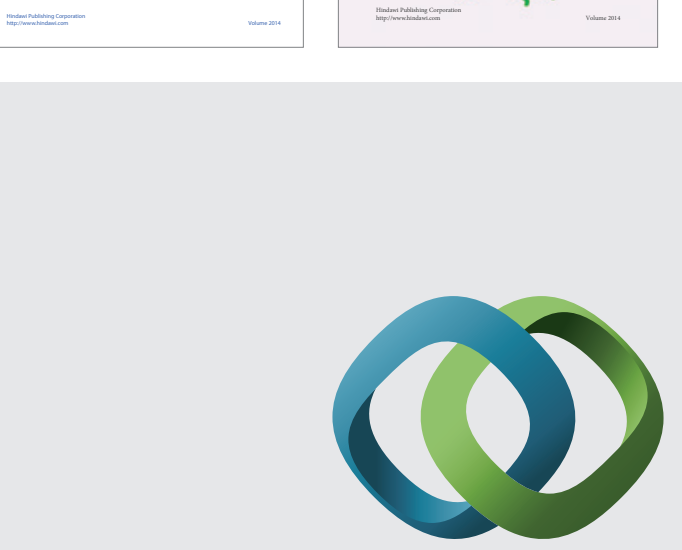

\section{Hindawi}

Submit your manuscripts at

http://www.hindawi.com
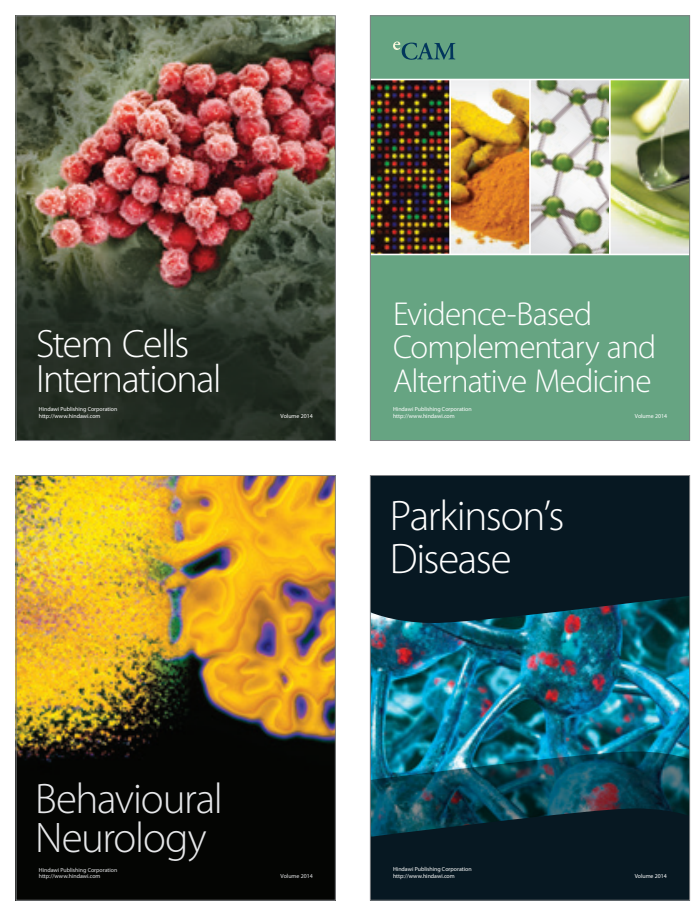

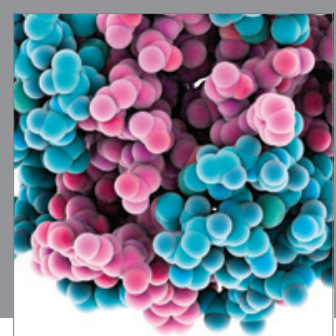

Journal of
Diabetes Research

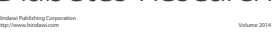

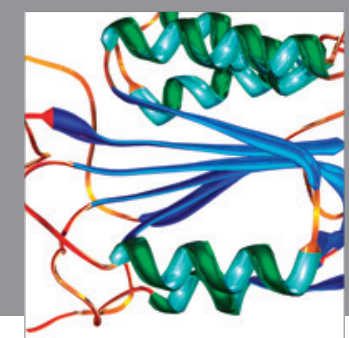

Disease Markers
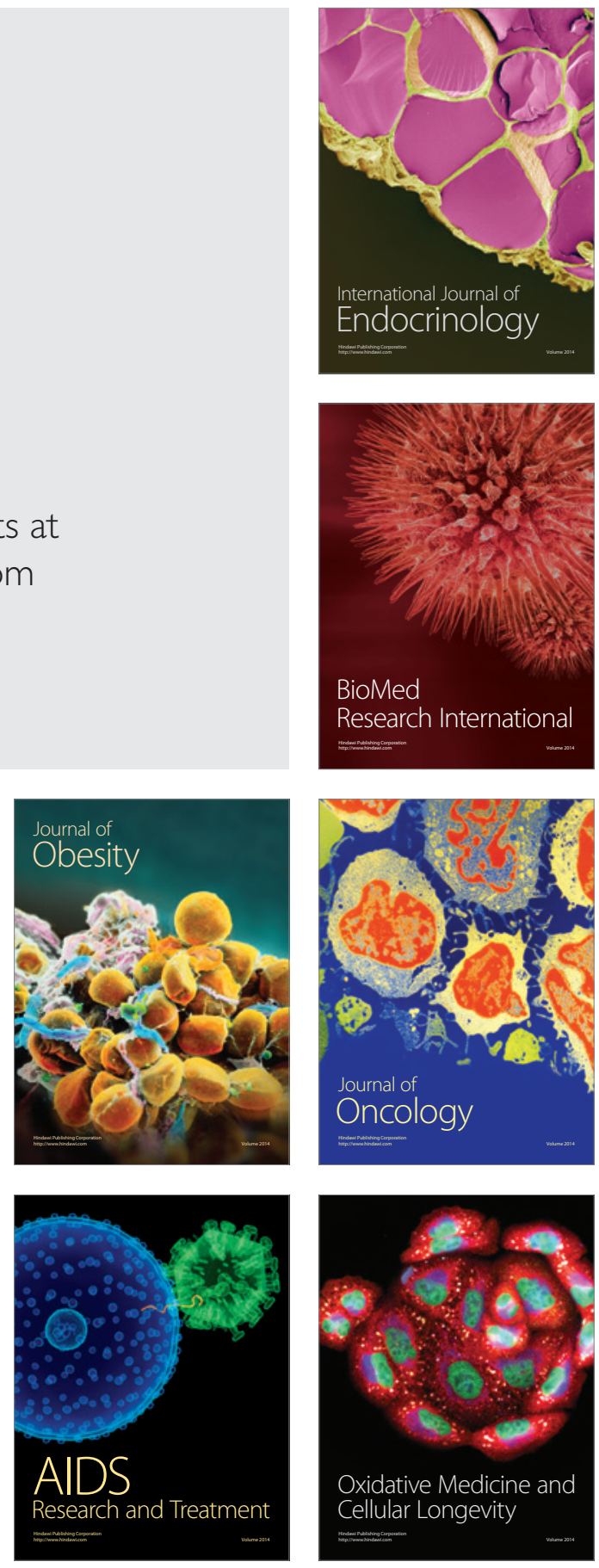